\author{
Dr. Vinita Pimpale \\ Associate Professor \\ R A Podar College of Commerce \& Economics. \\ vinitakris@gmail.com
}

\begin{abstract}
Coastal tourism and recreation are important parts of the largest and most rapidly growing activity in the world--- international tourism. Tourism and recreation-related development is one of the major factors shaping development patterns in the coastal zones of India. Hence, any analysis of India's interests in coasts and oceans must take account of its interrelated activities. Government at all levels must assume appropriate proactive roles to shape and guide coastal tourism development. This paper reviews the importance of coastal tourism and recreation to India and its citizens and identifies gaps where action is needed.
\end{abstract}

Key terms: Costal Tourism, recreation, tourist sites

\title{
Introduction
}

In this paper, the term "coastal tourism and recreation" embraces the full range of tourism, leisure, and recreationally oriented activities that take place in the coastal zone and the offshore coastal waters. These include coastal tourism development (hotels, resorts, restaurants, food industry, vacation homes, second homes, etc.), and the infrastructure supporting coastal development (retail businesses, marinas, fishing tackle stores, dive shops, fishing piers, recreational boating harbors, beaches, recreational fishing facilities, and the like). Also included is ecotourism and recreational activities such as recreational boating, cruises, swimming, recreational fishing, snorkeling and diving. Coastal tourism and recreation in this paper likewise includes the public and private programs affecting all the aforementioned activities.

Of all the activities that take place in coastal zones and the near-shore coastal ocean, none is increasing in both volume and diversity more than coastal tourism and recreation. Both the dynamic nature of this sector and its magnitude demand that it be actively taken into account in government plans, policies, and programs related to the coasts and ocean. Indeed, virtually all coastal and ocean issue areas affect coastal tourism and recreation either directly or indirectly. Clean water, healthy coastal habitats, and a safe, secure, and enjoyable environment are clearly fundamental to successful coastal tourism. Similarly, bountiful living marine resources (fish, shellfish, wetlands, coral reefs, etc.) are of critical importance to most recreational experiences. Security from risks associated with natural coastal hazards such as storms, hurricanes, tsunamis, and the like is a requisite for coastal tourism to be sustainable over the long term.

However, attractive coastal amenities exist in many foreign locations as well. Tour groups have choices that include Australia's Gold Coast or Fiji's very attractive beaches in addition to those found in Hawaii. Coastal tourism is becoming a highly competitive business as nations actively seek to draw increased numbers of visitors (and increased foreign earnings) to their shores. Moreover, given today's rapid pace of communications, the existence of poor water quality or 
degraded or eroding beaches is quickly communicated among networks of travel agents and others in the tourism marketing business.

The nation's coasts and coastal waters are of great value to countries both for their personal enjoyment and for the economic benefits these areas generate for coastal communities, coastal states, and for the nation as a whole $3 / 4$ benefits that can be sustainable indefinitely with proper foresight and enlightened public policies. But, these benefits cannot be taken for granted. Coastal habitats and the resources they support must be protected and, where necessary, restored. The quality of coastal waters must be maintained at a sufficiently high level to provide a healthy and aesthetically pleasing environment for water-based recreation. Similarly, swimming beaches must be maintained at an attractive and functional level even in the presence of accelerating sealevel rise and associated erosion, and possible increases in the frequency of coastal storms. The maintenance of safe conditions for recreational boating and underwater recreation (e.g., adequately marked waterways, timely weather information, rescue services, hyperbaric chambers, etc.) is also of great importance.

\section{Organization of the Paper}

Following a review of the importance of coastal tourism and recreation to Indian economy, including the contribution of foreign coastal tourism, a description of the existing policy framework affecting coastal tourism and recreation is provided. This covers such topics as:

- governmental promotional efforts regarding tourism;

- coastal planning and management (especially for setting of tourism facilities and provision for public access);

- efforts at attaining clean water and healthy coastal ecosystems;

- beach restoration programs;

- management of coastal security (including natural hazards and marine safety); and

- Special management challenges posed by ecotourism activities.

A discussion of the adequacy of the existing management framework in each of these areas is provided. Existing tools, programs, and arrangements for achieving sustainable coastal tourism are addressed, with emphasis on relevant developments on sustainable tourism at the international level. The final section of this paper presents options for consideration regarding the areas covered, and opportunities for cooperative action with coastal states and communities, the private sector, and nongovernmental organizations.

Along with the rest of India, Mumbai, its commercial capital, has witnessed an economic boom since the liberalization of 1991, the finance boom in the mid-nineties and the IT, export, services and BPO boom in this decade. The middle class in Mumbai is the segment most impacted by this boom and is the driver behind the consequent consumer boom. Upward mobility among Mumbaikars has led to a direct increase in consumer spending. Purchasing power has grown proportionately. This growth is most apparent in the city's real estate growth as well as a rapid growth in retailing and lifestyle expenditure among its citizens. Over the past few years, the city has seen large retailing organizations set up shop, aiming to grab a chunk of the growing share of disposable incomes among the middle class. Groups like Lifestyle, Pyramids, Shoppers' Stop, Trent and Big Bazaar have established chain stores across the city. International fashion labels such as Gucci and Armani are planning to set up retail stores in Mumbai. The city would have 
over 60 malls across the downtown and suburbs, all ready to tap into the vast suburban middle class.

The entire stretch from Sindhudurga to Ratnagiri has the threat of Tourism development while Thane, Tarapur and Dahanu are polluted with the industrial development. Increasing urbanization threat the coastal stretches from Bombay, Thane to Raigarh (Ali Bagh) The threat of aquafarms are mainly at Karakuran and Davidare taluks of Palghar districts in Maharashtra.

The possible destination in and around Mumbai: These are a few possible destinations around Mumbai where in our project concept can be exclusively applied and created

A. Marve, Manori, Gorai: North of Mumbai, and away from its busting crowds and pollution, are these three gems that have become popular havens for Mumbai's beleaguered fun lovers. Marve, the closest and the quietest are a lovely little fishing village. It has some beautiful bungalows owned by Mumbai's elite for weekend gateways. Low hills along the beach offer you extraordinary views of sunrise and sunset. Gorai and Manori, a little further away, are more crowded with revellers and are famous for all night beach parties. A fifteen-minute ferry ride from Marve or Borivali takes a person to Gorai and Manori.

B. Dahanu Bordi: Dahanu, a quite seaside town with a sprawling, uncluttered beach, is situated in Thane district. The Dahanu-Bordi stretch is $17 \mathrm{kms}$. This once-barren land thrived under Irani settlers, an earthy people. Dahanu is lined with fruit orchards and is famous for its chickoos. Accessible from Dahanu is Udwada - the 'Mecca of the Zoroastrians' - with a large, beautiful temple which houses their sacred fire.

\section{Bassein}

Bassein used to be a place for ship-building in the beginning of the seventeenth century. It was here that the Marathas besieged the Portuguese in 1739. The ruins of the Portuguese Fort still stand almost hidden by brushwood and palm groves. About $10 \mathrm{kms}$. Many Buddhist relics were discovered here. Nalasopara is believed to have been Gautama Buddha's birthplace in a previous life. To the north of Nalasopara is the Agar of Agashi and to the south the Agar of Bassein. About an hour by bus from Bassein station are the Vajreshwari temple and Akloli hot springs. Also easily accessible is Ganeshpuri with the Sadguru Nityanand Maharaj Samadhi Mandir, the Bhimeshwar temple and the other ashrams. There are several beautiful churches in Bassein, a reminder of the Portuguese presence.

\section{Mandwa - Kihim:}

Twelve miles north of Alibag on the north coast and easily accessible from Mumbai, Mandwa is a beautiful, untrodden beach. On a clear day one can enjoy a long, breathtaking view right up to the Gateway of India. Mandwa village too has a charm of its own- with its beautiful groves of coconut palms. Kihim beach, unspoilt and isolated, this beautiful place has a soothing effect on all city dwellers. For the nature lover Kihim has a lot of offer; woods brimming with wild flowers, rare butterflies and birds. Worth visiting is the Kolaba Fort, just a furlong away from the shore. $15 \mathrm{kms}$. from Alibag is 
Chaul, an historic place where one can spot Portuguese ruins, Buddhist caves, the Hamam Khana, a church, a temple and even a synagogue.

\section{E. Ganpatipule}

Visit the vast strech of unpolluted silver sands on the western cost of Maharashtra, bathed in the golden sunshine and silver moonlight, Lapped by gentle foam-flecked waves from the expanse of the arabian sea, Laced with the unforgettable aroma of fruits, flowers and mangroves. Ganapatiphule Land of the 400- year old Swayambhu ganapati and eager tourists. Set along the western coast of Maharashtra, is a small little village called Ganapatiphule. It is known for its serene sedate beach. Unlike most beaches which are spoilt by tourist traffic, the Ganapatiphule beach is as natural and pristine as ever. Even today, the waters are blue and the sands, white.

In addition to these there are a few small island off the coast near the gate way of India these are in the possession of the navy and are totally underutilized these can prove to be the best area where the entire project can be executed on a private island.

\section{Developing Marve, Manori, Gorai and Coastal Region}

In order to boost tourism in these areas the government should have planning have proper planning and development strategies. The main focus should be on developing the infrastructure. Infrastructure improvement for Marve, Gorai and Manori has to be examined in terms of transport, services and housing infrastructures. These include road and rail networks, sanitation and sewer disposal system, storm water drainage systems, slum improvement and housing repairs and retrofitting programmers. The dependent lifelines of Mumbai which include water supply, electric supply, telecom services, fuel, health, food supply etc, depend very much upon the effective functioning of these infrastructural facilities.

Power stations/Electrical installations (receiving station)

The electricity requirements of Marve, Gorai and Manori are met by the Tata Hydro-Electric system through three distribution agencies; namely the Brihan Mumbai Electric Supply and Transport Undertaking (BEST) in the island of Mumbai, the Brihinmumbai Suburban Electric Supply Company (BSES) covering areas of the western suburbs and southern parts of eastern suburbs and the Maharashtra State Electricity Board (MSEB) covering the Northern areas of the eastern suburbs

Transport infrastructure

The requirements of projected passenger traffic rise in vehicular density, and the increase in number of vehicles, both private and public, will put tremendous pressure on the existing transport infrastructure and road network. For reduction of road accidents, reducing disruptions resulting from floods and increasing the response time of the emergency services, a comprehensive mitigation strategy to improve the transport infrastructure becomes imperative.

Sanitation facilities

Although there has been no serious outbreak of any epidemic in the city during the last thirty years, and there has been a daily quality monitoring of water supply, sanitation facilities are 
inadequate. It is estimated that more than 40,000 toilets are required to achieve a ratio of 1:25 families.

The settlements along the nallahs are vulnerable to floods. Also, in the absence of training, soling and regular de-silting (cleaning), most of these nallahs have a tendency of flooding and choking. It is necessary that a programme of nallah training, soling and cleaning is undertaken rigorously through the Storm-water drainage department of the BMC.

\section{Concept}

Mumbai is a vast piece of land although being over crowded this place potentially still has a lot of places on the outskirts as well as around the island which is pretty empty with a lot of place to spare with the abundance of rich coastal features as well as natural environment, not so populated like its other concrete counterparts.

This can be either an island within short distance of Mumbai or a vast stretch of beach on the outskirts of the city.

The place is supposed to be created into a totally diversified region which can be identified as an individual resort or an individual small time village that would be if at all the possibility of creating it on an island favors.

The place shall feature the following Attractions: -

- Beach shacks

- Exclusively beach hotels cum resort

- Tempting cuisines from all over the world (specializing in sea food)

- Spas

- Aquatic wild life attraction

- Health therapies and massages

- Water sports

- most happening discos \&clubs

- Gyms

- Beauty saloons

- Beautiful landscapes and gardens with laser shows

- Private transport facilities

- Attractive packages

Health Spas and Therapies

Places like Kerala have seen a tremendous amount of tourism spending days and months for these magical therapies and treatment. Spas and Grande Spas offer a spectrum of authentic and traditional Indian wellness treatments and experiences in a stylish and soothing ambience. Drawing from ancient India healing wisdom and Ayurveda, Spas believe that a spa unfolds a way of life wherein the life force is the bedrock of wellness. Spas enrobe guests in exclusive experiences and environs whilst offering an array of signature treatments, yoga and meditation. The treatments include a choice of Indian, royal and holistic experiences, applications and ceremonies specially designed to maintain physical, mental and spiritual equilibrium.

Inspired by the ancient Indian science of the planning of space, spas unfold a refreshing idiom of spa design that emanates a harmonious balance of energy and elements in their restful tropical 
overtones, organic design and contemporary finishes. The spas are equipped with single and double treatment suites, beauty treatment rooms, meditation and yoga pavilions, relaxation pools and fully-equipped gyms. Highly trained and dedicated spa therapists offer treatments with unique products made from pure Indian herbs, Indian aromatherapy oils, natural creams and special ingredients.

The therapies offered shall be as follows: -

- Mud therapies

- Oil therapies

- Stone and gem therapies

- Steam therapies

- Aurvedic therapies

- Different kind of massages

- Steam \& saunas

These therapies shall enable us to cater to the customers the ultimate relaxation and rejuvenation that they seek.

Water sports offered

- Motor scooters

- Surfing

- Banana ride

- Water skiing

- Para gliding

- Para sailing

Discos, Parties and Beach Party Zones

The hotels shall feature the best of discos \& lounges while our added attraction shall be on the beach disc which can host small group private parties to a major event or festival party.

The place needs to be a major promoter of the festival seasons like the New Year's Eve.

Party zones shall be completely equipped with light effects, lasers, neon's, synthesizers, turn tables, Dj's spinning the coolest music, the places shall be equipped with full-fledged bars, and lounge restaurants. Where in all kinds of beverages alcoholic as well as non-alcoholic shall be served. The food would also be a variety of cuisines to choose from.

\section{Marketing Strategies}

The combination of sub-mixes chosen by a firm is usually called the marketing mix. The Tourist marketing mix includes different types of sub-mixes like product, price, promotion and distribution mix. The designing of sub-mixes is significant as it helps the marketer in conceiving the right ideas, particularly to raise the acceptability of the tourist product by stimulating and penetrating the demand.

Framing of a proper marketing mix is significant because it helps the tourist organization in accomplishing the objective and projecting a fair image.

Product Mix: 
Tourism is a composite product with components like attraction, facilities and transportation Attraction deserves an intensive care. It includes Natural site, places of historic interest, events and cultural attraction.

The facilities compliment attraction. The facilities include accommodation, food transportation and recreational facilities. The transportation component includes the vehicles and the infrastructure. Innovation in the tourism product helps raising the sensitivity. The users of the services are looking forward to better and improved product. The provider of the tourist product is the travel agent or the package tour. A well-conceived and designed package tour, covering a wide range of tourist attraction at an economic price, helps in attracting the potential tourist The travel agent performs numerous activities such as hotel arrangement and accommodation, sightseeing arrangement, domestic transport arrangement, air travel arrangement etc. In a true sense the tour agents and the travel agents are the vehicles who can give a fillip to the tourism industry, provided they are well trained.

Pricing

Pricing of the tourist product is complex, Geographical location of the destination, seasonality and varying demand affects the pricing decision.

In India, the pricing strategies become the important for promoting or contracting the tourism industry, since more than $40 \%$ of the total population is below the poverty line. In order to develop the tourism industry, more and more potential users are to be transformed into actual users. When a tourist prop loses to visit a particular place, the total cost on his traveling also includes the expenses incurred on transportation, accommodation and communication.

A liberal pricing strategy is found to be a productive pricing decision, particularly in case of tourism Industry. A pricing strategy which induces low-income group people, students and retired persons can be more effective. This is possible if the government offers concessional and subsidized infrastructural facilities to the potential tourist below the average income.

The different pricing methods generally used are cost based pricing, demand based pricing and competition based pricing.

Promotion:

The promotion mix includes advertising, publicity, sales support and public relations. The purpose of promotion is to make available the information to the user. Advertising and sales promotion can be effective when supplemented by publicity and personal selling. Radio, T.V. newspapers, cinema and printing are some to the important vehicles for traveling of messages. An effective slogan raises the effectiveness of advertisement.

Another important component of the promotion mix is public relation. It helps in projecting the image of an organization. Public relation and publicity include regular articles and photographs of tour attraction, use of T.V. and travel journalist to promote editorial comment.

Public relation officer plays an important role. He should be efficient, active, intelligent, impressive and well behaved.

A good image projection can be made if the PRO manages the affairs like a professional. It is said that word-of-mouth is the best form of publicity. The word-of-mouth promotion is an important tool in tourism marketing.

Place 
The tourist centers should be located at suitable points. If the tourist spots are natural there is no question of selection. In a vast country like India with divergent socio-economic and cultural patterns, the promotion of domestic tourism encourages unity in diversity.

Infrastructural facilities, transport and communication are important for the development of tourist centers. The site selected should have natural surroundings, increased accessibility and improved amenities. At the same time, it is also important that the ecological balnce 4 is not disturbed Since growing ecological imbalances leads to pollution, some important steps like promoting afforestation., promotion and beautification may be undertaken in countering the side effects of atmospheric pollution and maintaining ecological balance.

People

The person who attend to the needs of the tourists from an essential ingredient in tourism marketing. Behind the counter the sales personnel are responsible or dealing with the customers. The airline and transportation crew interact with customers while traveling.

The resort or hotel representatives cater to the needs of the tourists when they reach the destination. The guide who interacts with the customers at the tourist location, all form the people element in tourism marketing.

\section{Process}

The size of the tourism firm determines the operation process of the firm. The following steps are involved in the delivery of the tourism product:

i. Provision of travel information.

ii. Preparation of itineraries.

iii. Liaison with providers of service.

iv. Planning and costing tours.

v. Ticketing.

vi. Provision of foreign currency and insurance.

Physical Evidence:

The attraction of the tourist is the experience and this must be tangibilised with the help of tangible items like comfortable seats while travelling, layout and design of the resort, ambiance etc.

As the production in tourism is intangible, there is no need to describe the product fully which can be done by providing an elaborate brochure that shows how different elements of the Programme are carefully planned to include all necessary information to make comfortable holiday.

Feasibility Study

Although this may be called a dream project. The feasibility of the very same is very high.

There have been such mammoth projects in fact projects that are way too bigger than this one which practically exist in today's world

For example, the artificially created crown in Bahrain, Dubai.

The financial requirement comes to a gross amount of $100-250$ crore rupees in order to execute the project.

The financial Planning can be done in this manner

- Proposed partnership and help from Maharashtra tourism board 
- Banks and financial institutions

- National and international investors.

The time span required for the creation of the entire project would range around $3-5$ years. The work force shall be recruited as per the qualifications that the job may demand, wherein the major work force would be from Mumbai itself. Hence creating employment as well as generating strong revenue, empowering the city's economy.

\section{Conclusion:}

Through the CRZ program, coastal states build in their own regulatory approaches such as construction setback lines, storm-resistant building codes, acquisition programs for hazardous areas, and the like. Recognizing the connections that should exist between the planning and management efforts under CRZ, and cognizant of the lessons being learned during storm events by the emergency management programs,

Advanced planning and follow-up are required to maintain a safe and secure environment for visitors. Tourists take their safety for granted when they go to the beach or visit a coastal resort or even rent a sailboat for the day. Yet the coast is inherently a place with real risks, even under good weather conditions. Swimmers can drown and boats can collide or go aground, poisonous jellyfish can sting. And, of course, episodic large storms and hurricanes can have devastating consequences in coastal areas heavily populated with visitors.

Increasing numbers of Indians find themselves on the nation's waterways in connection with recreational boating, fishing, traveling and diving, and so on. Maintaining an adequate level of

safety and accident prevention requires properly marked channels, rescue services, oversight of boating safety requirements (e.g., life jackets and other emergency equipment), and monitoring and enforcement of boating operations, including so-called "thrill craft." While some of these duties can be performed by local and state authorities, the maintenance of safe and well-marked waterways and maritime safety in general has traditionally been a federal government responsibility. In any event, the federal government is in the best position to ensure than an adequately comprehensive safety program is in place in coastal areas.

\section{References}

- Ashe, J. W. (2005), Tourism investment as a tool for development and poverty reduction: The experience in Small Island Developing States (SIDS), Trade and Investment, The Commonwealth Finance Ministers Meeting 2005, Barbados.

- Beirman, D. (2003), Restoring tourism destinations in crisis: A strategic marketing approach, Cabi Publishing, Wallingford

- Inskeep, E. (1991), Tourism Planning: An Integrated and Sustainable Development Approach, John Wiley and Sons, Toronto

- Kanji, F. (2006), A global perspective on the challenges of coastal tourism, Coastal development Centre, Bangkok. 